\title{
PENERAPAN SUPERVISI PENDIDIKAN DALAM MENINGKATKAN KOMPETENSI PEDAGOGIK DAN PROFESIONALITAS GURU
}

\author{
Oleh: \\ Sonia Melsa Nurjannah (17002076) \\ Universitas Negeri Padang \\ Email:
}

Soniamelsa12@gmail.com

Kata kunci: Supervisi Pendidikan, Kompetensi Guru, Pengembangan

Profesionalitas Guru

\begin{abstract}
ABSTRAK
Dibandingkan dengan negara lainnya prestasi akademik Indonesia masih sangat jauh tertinggal. Kualitas pendidikan yang diharapkan masih sangat jauh dari yang diharapkan. Supervisi memiliki peranan yang sangat penting dalam pendidikan. Dengan adanya supervisi maka kualitas pendidikan dapat ditingkatkan. Pemberian supervisi ini berguna untuk meningkatkan kualitas pedagogi guru yang pada muara akhirnya adalah untuk meningkatkan prestasi belajar siswa. Peningkatan kualitas hasil belajar siswa hendaknya dilaksanakan secara berkesinambungan dengan memperhatikan perkembangan ilmu pengetahuan, teknologi, serta sosial dan masyarakat. Dalam upaya meningkatkan kompetensi pedagogi guru yang profesional maka perlu diterapkan teknik supervisi, menumbuhkan budaya organisasi pembelajar, dan kegiatan pelatihan.
\end{abstract}

\section{A. Latar Belakang}

\section{Pentingnya Supervisi dan Kondisi Supervisi di Sekolah Dasar}

Untuk meningkatkan reformasi pendidikan yang lebih baik tidak cukup hanya perubahan dalam sektor kurikulum saja, baik itu struktur ataupun prosedur penulisannya. Perubahan pada kurikulum akan lebih bermakna 
apabila diikuti dengan perubahan praktik pembelajaran baik di kelas maupun di luar kelas. Kemampuan guru dalam menerapkan dan mengaktualisasikan kurikulum sangat menentukan keberhasilan implementasi kurikulum tersebut. Hal yang paling sering menjadi penyebab utama ketidakberhasilan penerapan kurikulum ini adalah kurangnya pengetahuan, keterampilan, dan kemampuan guru dalam memahami tugas-tugas yang harus dilaksanakannya. Hal ini berarti guru menjadi kunci dalam kesuksesan keterlaksanaan kurikulum ini.

Dalam proses belajar mengajar di kelas guru memegang peranan yang sangat penting. Rendahnya prestasi belajar siswa berkaitan erat dengan kemampuan guru dalam mengelola pembelajaran yang rendah. Tidak hanya itu, para siswa juga membutuhkan perhatian dan arahan yang baik dari guru untuk dapat belajar dengan baik. Untuk menjadi guru yang profesional maka guru dituntut untuk memahami dan menerapkan berbagai media pembelajaran di dalam proses belajar mengajar di kelas.

Berkembang tidaknya suatu pelaksanaan tugas guru, sebagian besar sangat ditentukan oleh kemampuan guru tersebut dalam merencanakan kegiatan belajar sebelum mengajar. Namun, dalam kenyataan sehari-hari masih ada guru yang belum mampu atau tidak memiliki kemampuan dalam merencanakan kegiatan pembelajaran serta ada di antara guru yang tidak ada persiapan dalam mengajar.

Menurut Sabandi (Sabandi, 2013) Berkembang tidaknya suatu kreativitas guru dalam melaksanakan kinerja untuk kompetensinya dalam proses belajar mengajar dapat mengakibatkan proses belajar menjadi kurang optimal sehingga materi yang disajikan menjadi tidak tuntas.

\section{Rumusan Masalah}

a. Apa pendekatan yang dapat dilakukan oleh kepala sekolah dan pengawas dalam meningkatkan profesionalitas guru?

b. Bagaimana meningkatkan kompetensi pedagogik guru dalam meningkatkan kualitas pembelajaran?

\section{Tujuan Penulisan}


a. Untuk mengetahui beberapa pendekatan supervisi yang dapat dilakukan supervisor kepada guru.

b. Untuk mengetahui cara meningkatkan kompetensi guru dalam meningkatkan kualitas pembelajaran.

c. Untuk meningkatkan kualitas guru dalam mengimplementasikan kurikulum.

\section{B. Pembahasan}

\section{Ringkasan Artikel}

Menurut Jaenudin (Jaenudin, 2017) sebagai seorang supervisor meningkatkan kualitas guru agar dapat meningkatkan kualitas pembelajaran merupakan tugas utama dari supervisor. Yang mana jabatan dari supervisor ini di sekolah adalah pengawas dan kepada sekolah. Fokus utama dari peran supervisor ini adalah menemukan kesalahan guru yang mungkin terjadi dan melenceng dari standar kerja baku dari otoritas pendidikan.

Dalam perkembangan supervisi pada masa sekarang ini lebih menekankan kepada upaya untuk meningkatkan kompetensi pedagogi dan keprofesionalan guru yang berkelanjutan. Supervisor dengan jumlah yang sangat terbatas dengan kemampuan yang variatif jika dibandingkan dengan jumlah guru yang lebih banyak tentu tidak akan mampu melayani supervisi guru secara keseluruhan. Maka guru perlu untuk berinisiatif untuk menganalisis kualitas pembelajaran dan menemukan permasalahan pembelajaran untuk diupayakan kualitasnya secara berkelanjutan.

Dalam Undang-Undang Nomor 14 Tahun 2015 tentang guru dan dosen, menyebutkan ada empat kompetensi yang harus dimiliki oleh seorang guru yaitu kompetensi kepribadian, kompetensi pedagogi, kompetensi profesional, dan kompetensi sosial. Para pakar pendidikan sudah banyak menegaskan bahwa seseorang akan bekerja secara profesional apabila ia memiliki kompetensi secara utuh. Seseorang tidak akan dapat bekerja secara profesional apabila ia hanya memenuhi salah satu antara keempat komponen tersebut. Kompetensi tersebut merupakan perpaduan antara kemampuan dan 
motivasi. Betapapun tingginya kemampuan seseorang apabila tidak akan bekerja secara profesional, maka ia tidak memiliki motivasi kerja yang tinggi dalam melaksanakan tugas-tugasnya. Sebaliknya betapapun tingginya motivasi kerja seseorang jika tidak bekerja secara profesional maka ia tidak memiliki kemampuan yang tinggi dalam mengerjakan tugas-tugasnya.

\section{Kajian Analisis}

\section{Supervisi Pendidikan dan Pendekatannya}

Glickman (Sudrajat, 2011) mengungkapkan "supervisi akademik atau supervisi pendidikan adalah serangkaian kegiatan membantu guru mengembangkan kemampuannya mengelola proses pembelajaran demi pencapaian tujuan pembelajaran”. Sementara itu Daresh (Rahman, 2011) menyebutkan "supervisi akademik merupakan upaya membantu guru-guru mengembangkan kemampuannya dalam mencapai tujuan pembelajaran.

Supervisor sebagai penanggung jawab keberhasilan penyelenggaraan pendidikan dapat dapat dilakukan dengan beberapa pendekatan untuk meningkatkan kompetensi dan keprofesionalitas seorang guru, diantaranya supervisi klinis, supervisi pengembangan, dan supervisi diferensial.

Pada supervisi klinis yang menjadi elemen kunci pada proses supervisi klinis adalah mengumpulkan data pada kelas yang sebenarnya. Goldhammer et al (1980: 19) mengatakan "supervisi klinis adalah fase supervisi pembelajaran yang mendapatkan data peristiwa mengajar sebenarnya dari pengamatan tangan pertama, dengan cara interaksi tatap muka antara supervisor dengan guru dalam menganalisis perilaku mengajar dan kegiatan meningkatkan pengajaran".

Pada supervisi pengembangan, model ini didasarkan pada asumsi bahwa guru sebenarnya memilki variasi pengalaman, kemampuan, dan tingkat pengembangan karier yang berbeda. Oleh karena itu, supervisor menentukan kebutuhan supervisi guru berdasarkan, perbedaan individual, keahlian, dan komitmen. 
Supervisi diferensial menurut Glatthorn (1997: 3) bahwa supervisi diferensial merupakan pendekatan supervisi yang menyediakan pilihan jenis supervisi dan evaluasi yang sesuai dengan kebutuhan guru. Supervisi diferensial dilaksanakan dengan mempertimbangkan perbedaan individual antara guru dan hubungan manusia antara supervisor dan guru. Prinsip pada supervisi diferensial ini adalah "keadaan yang berbeda dan memerlukan pendekatan yang berbeda" yang pada intinya menunjuk pada keprofesionalan seorang supervisor dalam memberikan supervisi.

Selain itu, untuk meningkatkan kualitas pembelajaran yang lebih efektif juga dapat dilakukan dengan melakukan pelatihan dan menciptakan budaya organisasi mengajar. Menurut Mahaparto (2010: 285) pelatihan adalah kegiatan yang diselenggarakan untuk meningkatkan pengetahuan dan keterampilan orang-orang dengan tujuan tertentu. Sama halnya dengan pelatihan peningkatan kualitas pembelajarn guru juga dapat dilakukan melalui budaya belajar organisasi.

\section{Kompetensi Pedagogi Guru}

Kompeten dan kompetensi adalah dua kata yang sering digunakan dalam lingkup bisnis maupun organisasi pemerintah belakangan ini. Saking seringnya, makna hakiki dari kedua kata itu pun sering disederhanakan. Kompeten dan kompetensi misalnya dianggap sama dengan keahlian dan kemampuan. Kompetensi individu tidak bisa berdiri sendiri hanya sebatas kebiasaan atau kemampuan seseorang, tetapi ia berkaitan erat dengan tugas dan profesi yang dijalankan orang itu dalam pekerjaan.

kompetensi diakui sebagai pemegang faktor penting dalam keberhasilan seseorang dalam pekerjaannya. Sebagai contoh guru sebagai salah satu profesi, Undang-Undang RI Nomor 14 Tahun 2005 tentang guru dan dosen menyatakan bahwa guru wajib memiliki kualifikasi akademik, kompetensi, sertifikat pendidik, sehat jasmani dan rohani, serta memilki kemampuan untuk mewujudkan tujuan pendidikan nasional. Selanjutnya Mendiknas RI melalui Permen Nomor 16 Tahun 2007 menetapkan standar kualifikasi akademik dan kompetensi guru. Identifikasi guru yang tepat dianggap 
memilki nilai prediksi yang valid untuk keberhasilan guru dalam pekerjaannya.

\section{Kesimpulan dan Saran}

\section{Kesimpulan}

Supervisi pendidikan merupakan serangkaian kegiatan untuk membantu guru-guru mengembangkan kemampuannya, namun dalam pelaksanaannya terlebih dahulu perlu diadakan penilaian kemauan guru sehingga bisa dikembangkan aspek yang perlu dikembangkan dan cara mengembangkannya.

Supervisi akademik yang dilakukan kepala sekolah dan pengawas kepada guru yang memiliki masalah dalam kinerjanya, akan membantu meningkatkan kompetensi pedagogi dan profesionalitas guru secara berkelanjutan. Pengembangan kompetensi guru dan profesionalitas guru yang berkelanjutan memang sangat penting untuk dilakukan seiring dengan perkembangan ilmu pengetahuan, teknologi, sosial ekonomi dan budaya. Berbagai pendekatan dapat dilakukan dalam rangka mewujudkan tujuan dari supervisi ini. Beberapa pendekatan ini antara lain teknik supervisi, budaya organisasi pembelajaran, dan pelatihan. Dengan adanya beberapa pendekatan supervisi tersebut maka upaya meningkatkan kompetensi pedagogi dan profesionalitas guru dapat tercapai.

\section{Saran}

1. Kegiatan supervisi pendidikan ini sangat baik dilakukan untuk membina guru dalam meningkatkan kompetensi dan kinerjanya. Maka sebaiknya kegiatan ini dilaksanakan terencana dan berkesinambungan.

2. Sebaiknya supervisi pendidikan ini dilakukan pada setiap guru yang mengajar.

\section{REFERENSI}

Jaenudin, U. (2017). No Title PENERAPAN SUPERVISI AKADEMIK UNTUK MENINGKATKAN KOMPETENSI PEDAGOGIK GURU DALAM 
MENYUSUN RPP SDN KALAPADUA KECAMATAN CIBOGO

KABUPATEN SUBANG TAHUN 2017. Pedagogi, 3(2), 8. Retrieved from

file://C:/Users/ASUS/Downloads/84-85-331-2-10-20180221 (2).pdf

Sabandi, A. (2013). No Title SUPERVISI PENDIDIKAN UNTUK PENGEMBANGAN PROFESIONALITAS GURU BERKELANJUTAN.

Pedagogi, XIII(2), 14. Retrieved from

http://ejournal.unp.ac.id/index.php/pedagogi/article/view/4275 